\title{
Investigation of entomophobia among agricultural students: the case of Shiraz University, Iran
}

\author{
D. Hayati, ${ }^{1}$ K. Minaei ${ }^{2}$ \\ ${ }^{1}$ Department of Agricultural Extension and Education; ${ }^{2}$ Department of Plant Protection, \\ College of Agriculture, Shiraz University, Shiraz, Iran
}

\begin{abstract}
The most significant impact of some insects involves their role as primary vectors and alternate hosts of many devastating infectious disease agents. They also affect the health of vertebrates directly by triggering altered mental states such as entomophobia. Investigate entomophobia among agricultural students as they are an important group of people who deal with and are involved with insects in various ways. Understanding those factors that affect their attitudes to insects was the main objective of this study. The findings revealed that fear of insects are a current sense among them. Gender, having previous experience toward working with insects, and passing entomology course were factors that showed positive correlation with the entomophobia of respondents. Some related discussions and recommendations are presented at the end of this manuscript.
\end{abstract}

\section{Introduction}

Insects are the dominant group of animals on Earth today

Correspondence: Kambiz Minaei, Department of Plant Protection, College of Agriculture, Shiraz University, Shiraz, Iran.

E-mail: kminaei@shirazu.ac.ir

Key words: Agricultural students; entomophobia; fear of insects; Iran.

Acknowledgements: the authors are particularly grateful to Ziba Najafi for her help in statistical analysis. Many colleagues as well as students in College of Agriculture, Shiraz University are thanked for their help in filling the questionnaires. Three anonymous reviewers have been highly appreciated for their suggestions on an early draft of this paper.

Received for publication: 2 November 2014.

Revision received: 22 January 2015.

Accepted for publication: 29 January 2015.

(C) Copyright D. Hayati and K. Minaei, 2015

Licensee PAGEPress, Italy

Journal of Entomological and Acarological Research 2015; $47: 4817$

doi:10.4081/jear.2015.4817

This article is distributed under the terms of the Creative Commons Attribution Noncommercial License (by-nc 3.0) which permits any noncommercial use, distribution, and reproduction in any medium, provided the original author(s) and source are credited.
(Triplehorn \& Johnson, 2005). They are intimately associated with our survival. They are important because of their diversity, ecological roles and influences on agriculture, human health and natural resources (Scudder, 2009). Most insects are beneficial in some way. They may dominate food chains and food webs in both volume and numbers. Feeding specializations of different insect groups include ingestion of detritus, rotting materials, living and dead wood, and fungi (Villani \& Wright, 1990), aquatic filter feeding and grazing (Ward, 1992), herbivory (Bernays, 1998), and predation and parasitism (Symondson et al., 2002). Moreover, about $85 \%$ of angiosperm plants are pollinated by insects (Grimaldi and Engel, 2005). However, insects also influence animal and human health in multiple ways. The most significant impact involves their role as primary vectors and alternate hosts of many devastating infectious disease agents. Parasitic agents transmitted by hematophagous arthropods include filariae, protozoa, bacteria, rickettsiae, and viruses. These creatures also affect the health of vertebrates directly by triggering altered mental states including entomophobia. Delusional parasitosis (Ekbom's syndrome), including entomophobia, is a form of psychosis whose victims acquire a strong delusional belief that they are infested with parasites, whereas in reality none is present (Webb, 1993). In particular, entomophobia is defined as an abnormal fear of insects and mites, and at its most extreme this can lead to serious psychological problems that require professional treatment (Hardy, 1988; Sabry et al., 2012). Entomophobia affects a heterogeneous group and the unfortunate result of this is a sharp decrease in office efficiency and morale.

Investigation of entomophobia among agricultural students was the main objective of this study. These students are an important group of people who deal with, and are involved with, insects in various ways; it is important to understand and mitigate those factors affecting this syndrome.

\section{Materials and methods}

The research undertaken was a quantitative survey. Undergraduate students (freshman, softomore, junior and senior) who were studying for their B.Sc. degree in the College of Agriculture in Shiraz University, Iran were the subject population. Using a stratified random sampling method and Krejcie and Morgan's sample size table, 307 students were selected as the sample group. An effort was made to include in the sample group students from all nine field of studies in the College of Agriculture (viz. Agricultural Economics, Agricultural Extension and Education, Agronomy, Animal Husbandry Sciences, Horticultural Sciences, Natural Resources, Plant Protection, Soil Sciences and Water Management). Data were collected using a questionnaire that first had been tested for validity by a panel of relevant experts and for reliability by conducting a pilot study. The Cronbach's 
$\alpha$ coefficient was about 0.84 . Descriptive and inference statistical methods were used to analyses the data.

\section{Results}

\section{Descriptive statistics}

Among the sample group, 65 students (21.2\%) declared a very high level of entomophobia and 72 students (23.5\%) high level; a further 73 students (23.8\%) specified an average level. Only 97 students declared a low level of entomophobia [55 students (17.9\%)] and [42 students (13.7\%)] a very low level (Figure 1).

The students were requested to declare their fear towards insects of four specific groups: dragonflies, beetles, bees and butterflies. $79 \%$ of respondents ranked beetles highest fear; about $61 \%$ gave second rank to bees; $60 \%$ gave third rank to dragonflies; and $87.1 \%$ gave fourth rank to butterflies toward their fear.

Respondents were questioned about insects that are injurious and damaging for humankind. About $55 \%$ of respondents believed that insects are not injurious and $62 \%$ of them believed that they are not damaging for humankind. This finding suggests their entomophobia is more psychological and it does not relate to their attitude toward injurious and damaging of insects.

Respondents' attitudes to insects being considered as human food were investigated. About $62 \%$ of them disagreed with the concept; only about $23 \%$ were supportive. About $15 \%$ were moderate in their attitude toward that idea.

\section{Inference statistics}

In order to investigate relationship between respondents' gender and their entomophobia, a T-test analysis was implemented (Table 1). Findings revealed females' score average toward their entomophobia (73.58) is significantly higher than males' score (53.17).

One of the research hypotheses was that if respondents have previous experience of working with insects, it may influence their entomophobia. A T-test analysis was implemented to examine that assumption (Table 2). Findings revealed those respondents who had previous experience toward working with insects had a significantly lower score for entomophobia in comparison with those who had not had such experience. It appears that having a working experience with insects can reduce entomophobia.

Normally, if a student undertakes and passes a University entomology course, she/he can be expected to have lower levels of fear of insects because most of our fears are subconscious. Therefore, an analysis of variance test was executed to elucidate differences in entomophobia scores among those students who passed, those who failed and those who are sitting the entomology course in the current semester (semester of this study). As apparent from Table 3 those respondents who passed the entomology course, had significantly lower levels of fear of insects in comparison to those who did not pass it.

Other measured variables like respondents' years of study in the University; extent of their willingness to undertake this field of study; place of birth and background (village or city); parents' characteristics; and age showed no significant correlation with the dependent variable (fear of insects).

\section{Discussion and conclusions}

Insects are enormously successful organisms, both in terms of number of species and abundance (Samways, 2006). In view of the fact that agricultural students are a group of people who generally deal with insects in their field of study, we expect that they should have lower levels of fear of insects in comparison to other people. But this study revealed that entomophobia is a common phenomenon among them. It can be concluded that agricultural students in Shiraz University have little understanding of the nature and functions of insects in the environment and society. It is true that a proportion of insects are harmful but most of them are beneficial for human life (van Driesche et al., 2008). Agricultural students' perceptions and their attitudes toward insects are very important. In the future they might be teachers or, significantly, may in some capacity have contact with farmers. Their fear of insects may transfer to their clients or students if in the future they

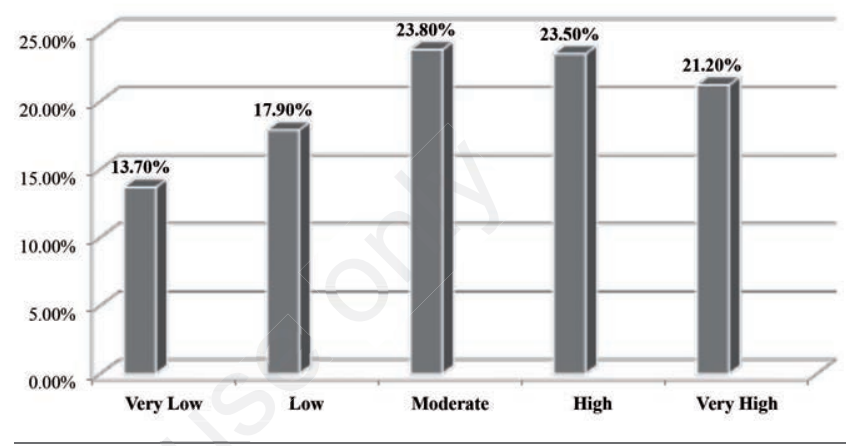

Figure 1. Entomophobia levels among respondents.

Table 1. T-test analysis to compare relationship between respondents' gender and their entomophobia.

\begin{tabular}{lcccc} 
Gender & Mean & SD & T & P-value \\
Female & 73.58 & 26.2 & \multirow{2}{*}{6.79} & 0.000 \\
Male & 53.17 & 25.3 & & \\
\hline
\end{tabular}

SD, standard deviation. Range: 11-110.

Table 2. T-test analysis to compare relationship between having previous experience of working with insects and entomophobia.

\begin{tabular}{lrrrr}
$\begin{array}{l}\text { Previous experience } \\
\text { of working with insects }\end{array}$ & Mean & SD & T & P-value \\
Yes & 51.95 & 24.3 & -4.259 & 0.000 \\
No & 68.56 & 27.4 & & \\
\hline
\end{tabular}

SD, standard deviation. Range: 11-110.

Table 3. Analysis of variance test to compare incidence of entomophobia in groups of respondents who passed or failed the entomology course.

$\begin{array}{lcccc}\begin{array}{l}\text { Dependent } \\ \text { variable }\end{array} & \begin{array}{c}\text { Passed Entomology } \\ \text { course }\end{array} & \text { Mean } & \text { F } & \text { P-value } \\ & \text { Yes } & 60.09^{\mathrm{a}} & & \\ \text { Fear of insects } & \text { No } & 68.64^{\mathrm{b}} & 3.493 & 0.032 \\ & \text { Current term } & 61.07^{\mathrm{ab}} & & \\ & \end{array}$

$\mathrm{a,b}$ Means with the same superscript letters had no significant difference according to least significant difference test. Range: 11-110. 
are considered as experts on insects. Similarly, their fear of insects may affect their authority among experienced farmers, and lead to them being ridiculed. In a similar study that been conducted in University of medical Science, Tehran, Iran (Firoozfar et al., 2012), $82.3 \%$ of students had problem when exposed to insects.

Another great challenge for insect conservation is the challenge of perceptions. Even among some general conservation practitioners, insects are often considered insignificant or given scant attention. This lack of appreciation of insects can reach major proportions among some sectors of human society, who may only recognize the dirty cockroach and the nuisance fly. Yet there is a growing awareness and even fondness for some insects (Samways, 2007). With a growing world population and increasingly demanding consumers, the production of sufficient protein from livestock, poultry, and fish represents a serious challenge for the future. Approximately 1900 insect species are eaten worldwide, mainly in developing countries (van Huis, 2013).

Insects provide more than economic or environmental benefits; characteristics of certain insects make them useful models for understanding general biological processes. For instance, the short generation time, high fecundity, and ease of laboratory rearing and manipulation of the vinegar fly, Drosophila melanogaster, has made it a model research organism (0'Grady, 2003). Studies of social insects, notably hymenopterans such as ants and bees, have allowed us to understand the evolution and maintenance of social behaviours such as altruism (Crespi \& Choe, 1997). Moreover, some early holistic concepts in ecology, for example ecosystem and niche, came from scientists studying freshwater systems where insects dominate (Gullan \& Cranston, 2005).

Insect conservation is still in its infancy (Pyle et al., 1981), but the conservation of insects is of increasing public concern. Insects are the major component of macroscopic biodiversity and, for this reason alone, we should try to understand them better. One might expect that passing courses like entomology would alleviate students' fears of insects, but the findings of this study are that this is not so. One of the reasons may be to do with the mode of presentation of such courses in the University. Those students who take those courses generally deal more with dead or taxidermy insects than with live insects. Group behaviour may have an influence, too, with students responding to fears of their cohort. It is recommended that lecturers of entomology courses make greater opportunities for students to deal with live insects so that their entomophobia will be alleviated, significantly and purposefully.

\section{References}

BERNAYS E.A., 1998 - Evolution of feeding behavior in insect herbivores. - BioSci. 48: 35-44.
CRESPI B.J., CHOE J.C., 1997 - Explanation and evolution of social systems. In: CHOE J.C., CRESPI B.J., eds., Social behavior in insects and arachnids. - Cambridge University Press, Cambridge: 499-524.

FIR00ZFAR F., BANIARDALANI M., MOOSA-KAZEMI S.H., 2012 Knowledge, attitudes and practices study in relation to entomophobia and its application in vector-borne-diseases. - Asian Pac. J. Trop. Biomed. 2: S1135-S1137.

GRIMALDI D., ENGEL M.S., 2005 - Evolution of the Insects. - Cambridge University Press, New York.

GULLAN P.J., CRANSTON P.S., 2005 - The insects: an outline of entomology. - John Wiley \& Sons, Chichester.

HARDY T.N., 1988 - Entomophobia. The case for Miss Muffet. - Bullent. Soc. Am. 34: 64-69.

0'GRADY P.M., 2003 - Drosophila melanogaster. In: RESH VINCENT H., CARDÉ R.T., eds., Encyclopedia of insects. - Academic Press, New York: 345-348.

PYLE R., BENTZIEN M., OPLER P., 1981 - Insect conservation. - Annu. Rev. Entomol. 26: 233-258.

SABRY A.H., FOUAD M A., MORSY A.T., 2012 - Entomophobia, acarophobia, parasitic dermatophobia or delusional parasitosis. - J. Egypt. Soc. Parasitol. 42: 417-430.

SAMWAYS M.J., 2006 - Insect extinctions and insect survival. - Conserv. Biol. 20: 245-46.

SAMWAYS M.J., 2007 - Insect conservation: a synthetic management approach. - Annu. Rev. Entomol. 52: 465-487.

SCUDDER G.G.E., 2009 - The importance of insects. In: FO0TTI R.G., ADLER P.H., eds., Insect biodiversity: science and society. Blackwell Publishing, 0xford: 7-32.

SYMONDSON W.O.C., SUNDERLAND K.D. GREENSTONE M.H., 2002 Can generalist predators be effective biocontrol agents? - Annu. Rev. Entomol. 47: 561-594.

TRIPLEHORN C.A., JOHNSON N.F., 2005 - Borror and DeLong's Introduction to the study of insects. - Thomson Brooks/Cole, Belmont, CA.

VAN DRIESCHE R., HODDLE M., CENTER T., 2008. - Control of pests and weeds by natural enemies: an introduction to biological control. - Blackwell Publishing, Oxford.

VAN HUIS A., 2013 - Potential of insects as food and feed in assuring food security. - Annu. Rev. Entomol. 58: 563-583.

VILLANI M.G., WRIGHT R.J., 1990 - Environmental influences on soil macroarthropod behavior in agricultural systems. - Annu. Rev. Entomol. 35: 249-269.

WARD J.V., 1992 - Aquatic insect ecology. - John Wiley \& Sons, Chichester.

WEBB J.P., 1993 - Case histories of individuals with delusions of parasitosis in southern California and a proposed protocol for initiating effective medical assistance. - Bull. Soc. Vect. Ecologists 18: 16-24. 